\title{
Micro Credit Program of NGOs in Poverty Alleviation: An Empirical Study on Some Selected NGOs
}

\author{
Jannatul Ferdous \\ Department of Public Administration, Comilla University,Bangladesh.
}

\begin{abstract}
In the recent year poverty alleviation has become one of the burning issues worldwide. A systematic development of a nation mainly depends on the proper alleviation of poverty. For this reason poverty alleviation have become global challenges, especially in the developing country like Bangladesh. The micro credit program is playing a vital role in the poverty alleviation. In parallel of government of a country, many NGOs and economical institutions have initiated different activities on the basis of Microcredit programs to alleviate the poverty. Therefore, the objective of this study is to show how micro credit works to improve the quality of poor targeted groups and reduce poverty and how it affects the living standard of the poor people in the study area. Several micro credit institutions are working in the study area. Grameen Bank, BRAC, ASA, are some of the most prominent of them. These institutions are working tremendously for the empowerment, poverty reduction and improvement of living standards for the poor people in the study area. However, the objective of this paper is to analyzethe potential contribution of NGOs and the role of micro credit more generally, to economic development, poverty alleviation and constraints inhibiting their future development in Bangladesh.
\end{abstract}

Key words: NGO,Poverty Alleviation,Microcredit,Development

\section{Introduction}

BANGLADESH is a heavily populated state and with a thickness of 834 populations in for each square kilometer, the quantity of inhabitants is 160.5 million. Recurring natural catastrophefor instance flood, corrosion and tornado gives extranuisance to the statein addition;People are trailing their asylum and lifetherefore. Outstandingprogress has been observed red in spite of the recurrent natural disaster hit in the States. Paucity jump downwardas of $57 \%$ to $40 \%$ and standard GDP growth augmented in excess of the previous six time is $6 \%$ in 1990's [1]. It is frequentlydisputed that to serve up the deprived the monetarydivision in low-income nations has unsuccessful. Banks and additionalmonetary institutions normallyneed significant security, have a favorite for elevated income and towering loan customers, and have long and technicalrequest proceduresby means ofesteem to the official sector. And, moneylenderstypicallyaccusevery high interest, tax, tend to rate too low collateral, and frequently allow chauvinistic and/or bigot attitudes to show lending choicesby means ofhigh opinion to the casual sector. Over the earlier period two decades sinceanincompletereply to this breakdown, there has been noteworthydevelopedduring what containerisnamed "micro-credit". So as to foster income cohort and scarcity reduction during ornamental self-employment [2]. Micro-credit is fundamentally the dispersal of little collateral-free credits to equallyaccountable borrowers in collections.It is significant to assess the poverty mitigationability of microcreditbeneaththese situations.

\section{Statement of the Problem}

Havinganextremely poor monetarymarketplace, a rising country is Bangladesh.Sinceneed of physical safetythedeprived people have not acquired access to officialfiscal institutions. On the additional hand thecasual moneylenders, accuse an excessive rate of attention, thus inhibiting deprivedhouseholds as of investing in creating income risingaction. Atlimitedstage Bangladesh does not containanappropriateunderneath of diminutive banks in service. Theprologue of the microcredit was a monetarymodernizationbeside the surroundings of a comparatively undeveloped official financial arrangement;Microcredit was initiated in the delayed seventies in Bangladesh. Forthe benefit less deprived households, who were previousmeasured 'non-bankable' beneath the habitual collateral-based monetarypractices; Microcredit is the stipulation of little loans provided are intended 
for the profitsgenerating character-employment actions. With collateral-free credits at reasonably pricedprices theMicro-Credit Organizations (MCOs) have been afforded to arrive at the deprivedand can thus assist the deprivedturn out to be self-employed.Todecrease the scarcity via promoting identity-employment amongst the poor and make sureconstancy in the profits of the deprived people is themajorobject of the microcredit. The query now arises becausetoward whether in the Bangladesh microcredit plan has been clever to addcompletelyto the comfort of the deprived people.In Bangladeshthequery is of great meaningintended foranalyzing the presentation of Micro-CreditOrganizations (MCOs). So in this region, it is of hugeinterest and commendable of forecast and investigatea situation of the stateas regardsthe scarcity status.

\section{Research Aim and Objective}

In Bangladesh what degree the microcredit programmers are gifted to transportoptimistic 'changes' andpayment in scarcitymitigationthis investigate seeks to observe.

Theexact objectives were since follows on the other hand.

- To appraisalrented by the NGO associates, theposition of microcredit

- For evaluating the efficiency ofmicrocredit on scarcityalleviation

- For providingproposals regarding the habits of civilizing the scarcity alleviation skill of microcredit.

\section{Limitations of the Study}

The lessons have some limits. Few limits are here out underneath:

a) Ifthe data could be in use from betterexample it would have been improved than what has been measuredat this point

b) If information could be in use as of all the scarcity alleviation actions in rustic areas in the lessonsit would have been improved

c) The preponderance of the loan respondents does not preserve any evidence to their spending, income, facts of bank credits, etc. they depend on top of their reminiscences, which complete the investigations incomplete therefore.

\section{Methodology}

Throughout the months of November 2013 to March, 2014 as of twenty-five villages of Comilla, Chandpur, Noakhali, and Brahman Baria Districts of Bangladesh The current study is based resting onmain data composed by the investigator herself.As well as Grameen Bank, Bangladesh Rural Advancement Committee (BRAC) and Association for Social Advancement (ASA)theinhabitants of the current research are the women associates of well-known Non-Government Associations (NGOs). Sincethe NGOs recognition agenda is mostly forwomen intended for this reason every one of the respondents elected for the currentlearning were women.By means of the assistwith pre-structured interview guides themain data have been composed by consultation the chosen 300 stakeholders. On or afterobtainable literature,yearly reports, textbooks, administration publication, agenda bulletins, etc.,the minorinformationhas been composed. The information thus composed have been agreedactually and investigated by means ofrelevant methods.

\section{History Of NGO and Micro-Credit in Bangladesh}

In Bangladesh, so as to understand the realsituation of the NGO's micro-credit plan in scarcitymitigation it is necessary to have anobviousidea regarding,the pursuit of progress of NGOs, some connectedconditions and its micro-credit plan in Bangladesh.

\section{What is NGOs?}

Innatural worldthe most ordinarymeanings of NGOs are unenthusiastic. As theseassociations are not fractions of the administration and do not live to make an income. Tocreateincome and administration exists to giveanecessaryarrangement of rule and order and endorseuniversalwelfare, commerceexists, but to give some armed forces or move forwarda number of causes in the dissimilar sectors of existence NGOs characteristicallysurvive.Helping a public reason NGOs are personal organizations [3].

Aself-governing from administration is anygroupororganizationandslightly than profitableobjects that has caring or helpful [4]. 
As a consequence of the individual plan of aperson or a group of persons to voluntarily take on developmental labor at the proletariatNGO resources anofficial non-profit non-partisan confidentialcorpse it aims at improving the life of the rustic poorin general speaking.By means ofathought of the kind of people needed in unpaidactions and the environment and range of NGO processthismeaning of an NGO offers one [5].

\section{History of NGOs in Bangladesh}

Merelya small number of NGOs maneuvered in the East Pakistan, then, now recognized as Bangladeshprevious to autonomy in 1971, just following the usualdisasteroccurred, in the coastal regions in 1970.Merely after the freedom war of 1971 The NGO operation in Bangladesh began andin the direction of tackle reprieve and treatment activities anamount of NGOs appearedthroughout this period.Turn over 1974 this wellbeingdirection in NGOs extended. They instigated growth activities through societygrowth approachthereafter;importance was set on boosting foodstuff production from side to side the use of recent farm equipmentthroughout this time. Therefore, some NGOs customizedtheir policy and administered their plans and armed forces to advantage thedeprived from the start of 1976. As the aim group move toward where the deprivedsimilarities with financialinterests were grouped jointly,this is at the presentrecognized. The NGOs tosupply various bearservices ranging as ofteaching, acclaim, income generation, physical condition, etc. to increasing the capability of the deprived and their financial empowerment, as well mobilizing the deprived [6].

\section{A short description of selected three NGOs}

\section{Association for Social Advancement (ASA)}

Inunusualdivisions of the stateASA is a foremost non-governmental association implementing scarcitymitigation. In 1978 it began towardservice and later onentirely changed its loom.Intodissimilarstages we can split its epoch of purpose in terms of loom. 'Foundation phase' is described by us theera 1978 to1984. ASA was occupied in the actions heading in towards exiting the low awareness level of the deprivedpopulaceat this stage. Prospect of awareness of the deprived was the center of this stage. Figure of actionssuch as consultation, awareness about lawful rights, work-related skill or messagesupport, repair and preparation for managerial are also included.By means of the transform of state of mind and approach the deprived people would finally take plan to alter their condition thefundamental; hypothesis was that. ASA began a new phase called the 'reformative phrase' and concentrated on the 'credit program for income age groupin the glow of this practice. Sandwiched between the years 1985 to 1991 thisstage extended. Contrastedwith the monetary need of the rusticpoor, chiefly the women, obtainabletribute based plans were not sufficient and it was time overwhelming to assemble the deprivedpopulaceto appoint them in publicgroup ASA's organization then sensed that.Focusingpowerfully on investments and credit for profitsage group from 1992thefigure of borrowers were concerningnamed'specialization phase'.Thestatistics of borrowers were regarding 150 thousand and enlarged to further than 1400 thousand immediately insix years. In the equivalentera the numeral of loansalso went awakethroughout the year 1992 [7].

\section{Bangladesh Rural Advancement Committee (BRAC)}

In 1972 by serving the immigrants returning residencefrom India to Shalla, a distant and an unapproachable community at the northeastern renter of the state BRAC in progress its ridejust after the freedom of Bangladesh.In their war-torn habitats and communities theasylums had to set up life anew. Byas long asthose materials required for residencemanufacture and apparatusesworn in earning a living BRAC helped the village dwellers. BRAC appreciated that release and modernization oriented actionswithin a small while BRAC initiated in 1973 a plan with an integrated society expansion approach in 200 communities in the similar area countingShallathereforeso as to get together long-term require of the populace. It was not acceptable to theexpansion of the village-wide society spirit.Later than the breakdown of the includedsocietyprogressmove toward BRAC led to assumeasubstitute approach to expansion - participatory growth program. BRAC commenced a credit helpful program for a number of the inferior subgroups explicitly, the landless, women and the fishermentherefore, in 1974.By means of the participatory expansionplan in several of the communities in which it was previously in accomplishment,theplan worked plane by plane. BRAC saw that because of the survival of a basic relationship inside the rural control structure the sharing of resources from side to side community expansion approach was actually benefiting the wealthy at the charge of the deprived in the 
community with the passageway of time. BRAC was persuaded thattherefore: (1) planthat is intended for the deprived must speak to the rural controlarrangement, and (2) for tackling the rural controlarrangement, the abilities and the organizations of the deprived must be urbanized. BRAC transferred from the idea of praise cooperatives intended for the deprived to the idea of organizing collections of the deprived - target collectionmove toward as a result in 1978 [8].

\section{Grameen Bank (G. B.)}

In Bangladesh the invention of Dr. Muhammad Yunus, a Vanderbilt cultured economics lecturer at Chittagong University and a social scientist is Grameen Bank. To experiment the theory that if monetarywealth are made existing to the deprived at sensible terms and circumstances, can they produceindustrious self-employment with no external help in 1976. The Grameen Bank created from a small deed research mission undertaken, the Grameen Bank as a scheme was started in 1979following three years of testing.Theschemedistorted into the Grameen bank, a particular financial organization for the rustic poorfrom side to sideadecreefollowing going through a procedure of learning until 1983. Even ifGrameen Bank is a dedicated Bank tillnowadays it is operational like NGO replica.

In Bangladesh The Grameen Bank is single of the majorityvictorious experiments in expanding acclaim to the deprived. Being deposit aside at the point in time of payment, which is accrued in the collection fundeachassociate of Grameen Bank is complete to put aside Tk. 1.00 per week by means of $5 \%$ of the credit amount. ForcreativeactionsGrameen bank merely provides micro-credit. With $20 \%$ attendance rate theacclaims are paid back in 50 equal payments, which is extremelyelevated companied to additionalNGOs [9].

\section{Micro-credit program of NGOs}

Because one of the majorityinfluential and effectivetools to reduce scarcity Micro-credit has haggard global concentration. Withanobservation to eliminatescarcity,assignment to go to the entrance of the deprivedpopulaceby means of appropriable monetaryservices (e. g. Micro-credit)agreed by them. Collectionbased praiseamenities are presented by all NGOs and in the state these collections are completed with person's women who are living beingbarred from the amenities of continuingprofitable banking system. They do not containsufficient resources, which they are able tostay as an advancein the store so they are barred in the intelligence. Micro-creditplan of NGOs has increased tremendous impetus as an effectual mode of shortagemitigationsocurrently [10].

\section{Micro- Credit And Poverty Reduction In Bangladesh: Respondent's View}

In this section, the researcher tried to analyze the impact of micro-credit program of above discussed three NGOs such as ASA, BRAC and Grameen Bank in alleviating and reducing poverty in 25 villages from different districts of Bangladesh. A questionnaire was provided to 300 stakeholders. Among them, 250respondents respondedproperly, which indicates response rate of $83.33 \%(250 / 300)$ [11].

\section{Impact of Micro-credit on poverty reduction and alleviation}

In order to hypothesize the impact of micro-credit program on poverty alleviation and reduction, 300 stakeholders were chosen as respondents, but among them 250 responded properly and the sample size has stoodsince 250. Several questions were asked for them. Some of them were yes/no questions and some were 5scale Likert scale questions where they express their opinion and converted it to a scale of 5 to 1 i.e. very satisfied to very dissatisfied.

\section{Response about the age of the respondents:}

The researcher used the frequency tabulation to present the age of the respondents. Table- 1 in the following presented the results: 
Table 1: Age of the Respondents

\begin{tabular}{|l|c|c|c|}
\hline Age of the respondents & Frequency & Percentage & $\begin{array}{c}\text { Cumulative } \\
\text { percentage }\end{array}$ \\
\hline $18-25$ years & 060 & 24.0 & 24.0 \\
\hline 26-35 years & 150 & 60.0 & 84.0 \\
\hline More than 35 years & 040 & 16.0 & 100.0 \\
\hline \multicolumn{1}{|c|}{ Total= } & $\mathbf{2 5 0}$ & $\mathbf{1 0 0 . 0}$ & \\
\hline
\end{tabular}

From the above table, it can be seen that $60 \%$ (150) of total respondents were within the range of 26-35 years. It indicates that women within this range of years took loan from the NGOs the most because during this time period they need to take the responsibility of their family, bear the expenses of their children and so on. More than 35 years of women normally could not dare to take loan because there leaves little chance for them to repay the loan within the scheduled time period[12].

Response about the timeframe of involvement with the micro-credit operation of NGOs by respondents: The researcher used the frequency tabulation to present the age of the respondents. Table- 2 in the following presented the results:

Table 2: Timeframe of involvement with micro-credit operation by respondents

\begin{tabular}{|l|c|c|c|c|}
\hline $\begin{array}{c}\text { Credit receiving } \\
\text { time period }\end{array}$ & BRAC & ASA & GB & Total \\
\hline 0-2 years & 40 & 10 & 10 & 60 \\
\hline 3-5 years & 45 & 25 & 10 & 80 \\
\hline 6-8 years & 15 & 10 & 15 & 40 \\
\hline 9-11 years & 25 & 18 & 15 & 58 \\
\hline 12-14 years & 05 & 02 & 05 & 12 \\
\hline Total $=$ & $\mathbf{1 3 0}$ & $\mathbf{6 5}$ & $\mathbf{5 5}$ & $\mathbf{2 5 0}$ \\
\hline Average $=$ & $\mathbf{6 . 5}$ & $\mathbf{7 . 5}$ & $\mathbf{8 . 5}$ & $\mathbf{7 . 5}$ \\
\hline
\end{tabular}

The question asked to the respondents was: For how long the respondents were involved in microcredit program of NGOs? From the above table, it can be concluded that the respondents on an average were involved in credit borrowings from the selected three NGOs for approximately 7.5 years. BRAC borrowers borrow for on an average of 6.5 years, whereas ASA borrowers borrow for on an average of 7.5 years and GB borrowers borrow for on an average of 8.5 years. Moreover, from the above table, it can also be seen that people took most of the loan for 3-5 years. Below this time period, they also took the loan. But taking loan greater than this period, ultimately, would increase their interest, thus they weren't interested until or unless extreme situation occurred. One more conclusion can be drawn from the table: the respondents were happy at taking a loan from NGOs because if they didn't like it or were not satisfied with it, they would have left the program within 2 years. Since they took a loan for more than 1 and 2 years, it indicates that micro-credit program plays a role in poverty reduction[13].

A response about the opinion of respondents about their satisfaction on the amount of credit they got from NGOs:

The researcher used the frequency tabulation to present the age of the respondents. Table- 3 in the following presented the results: 
Table 3: Satisfaction on the amount of credit got from NGOs

\begin{tabular}{|l|c|c|c|}
\hline \multirow{2}{*}{ Name of NGOs } & No. of Respondents & \multicolumn{2}{|c|}{ Options } \\
\cline { 3 - 4 } & & Yes & No \\
\hline BRAC & 130 & 40 & 90 \\
\hline ASA & 065 & 25 & 40 \\
\hline GB $\quad$ Total= & 055 & 20 & 35 \\
\hline \multicolumn{2}{|c|}{250} & $\mathbf{8 5}$ & $\mathbf{1 6 5}$ \\
\hline
\end{tabular}

The question asked to the respondents was: the respondents satisfied at the amount of credit they get from NGOs? From the above table, it can be concluded that the respondents on an average werenot satisfied at the amount of credit they got from NGOs. Majority respondents (165 out of 250 respondents) taking a loan from different NGOs answered in a same way that expressed their dissatisfaction towards the amount of credit they got from NGOs. There is a reason behind this. NGOs do this in order to increase the dependency of poor women to their institutions. Moreover, the NGOs aimof alleviating poverty so if they sanction full amount of money as a loan, credit holders won't be able to repay this loan amount within a prescheduled time period. But despite the fact, since credit holders could not get sufficient amount of the loan, they could not perform their expected business, this loan amount needs to be enhanced.Otherwise, this would become a barrier to poverty reduction in this country[14].

Response about the economic condition of the family of respondents before and after micro-credit loan:

The researcher used the frequency tabulation to present the age of the respondents. Table- 4 in the following presented the results:

Table 4: Change in economic condition before and after micro-credit loan

\begin{tabular}{|l|c|c|c|}
\hline \multirow{2}{*}{ Name of NGOs } & \multirow{2}{*}{$\begin{array}{c}\text { No. of } \\
\text { Respondents }\end{array}$} & $\begin{array}{c}|c| \\
\text { In better economic condition }\end{array}$ \\
\cline { 3 - 4 } & & $\begin{array}{c}\text { Before receiving loans from } \\
\text { NGOs }\end{array}$ & $\begin{array}{c}\text { After receiving a loan from } \\
\text { NGOs }\end{array}$ \\
\hline BRAC & 130 & 05 & 125 \\
\hline ASA & 065 & 03 & 062 \\
\hline GB & 055 & 02 & 053 \\
\hline \multicolumn{1}{|c|}{ Total= } & $\mathbf{2 5 0}$ & $\mathbf{1 0}$ & $\mathbf{2 4 0}$ \\
\hline
\end{tabular}

The question asked to the respondents was: does the respondent actually thinks her economic condition of families get better after taking the loan from NGOs than that of the earlier time when she did not take a loan? From the above table, it can be said that the majority of respondents ( 240 out of 250 respondents) expressed a positive attitudetowards the betterment of the economic condition of their family after taking the loan from NGOs. According to them, after taking the loan from the NGOs, they made themselves keep in better position than that of the previous. Moreover, after receiving the loan they invested this money in different sectors and from the investment they could earn a profit, which helped to make them better off than the previous. This micro-credit can contribute to alleviate the poverty from the country[15].

Response about the involvement of respondents in income generating activities:

The researcher used the frequency tabulation to present the age of the respondents. Table- 5 in the following presented the results:

Table 5: Involvement of respondents in income generating activities

\begin{tabular}{|l|c|c|c|}
\hline \multirow{2}{*}{ Name of NGOs } & No. of Respondents & \multicolumn{2}{|c|}{$\begin{array}{c}\text { Opinion on involved in income generating } \\
\text { activities }\end{array}$} \\
\cline { 2 - 4 } & & Yes & No \\
\hline BRAC & 130 & 120 & 10 \\
\hline ASA & 065 & 060 & 05 \\
\hline GB & 055 & 052 & 03 \\
\hline \multicolumn{1}{|c|}{ Total= } & $\mathbf{2 5 0}$ & $\mathbf{2 3 2}$ & $\mathbf{0 1 8}$ \\
\hline
\end{tabular}


The question asked to the respondents was: the respondents involvedherin income generating activities after taking the loan? From the above table, it can be concluded that the majority of respondents ( 232 out of 250 respondents) responded positively that they were involved in income generating activities after taking the loan. There exists a reason for this. The respondents need to pay the amount of the loan, so they need to involve themselves in income generating activities to repay the loan. On the other hand, their involvement contributes to the national income and GDP, which help to alleviate the poverty from the country [16].

\section{Response about the duration of involvement of respondents in income generating activities:}

The researcher used the frequency tabulation to present the age of the respondents. Table- 6 in the following presented the results:

Table 6: Duration of involvement of respondents in income generating activities

\begin{tabular}{|l|c|c|c|}
\hline \multirow{2}{*}{ Name of NGOs } & \multirow{2}{*}{ No. of Respondents } & \multicolumn{2}{|c|}{ Opinion } \\
\cline { 3 - 4 } & & Before receiving loans from NGOs & After receiving a loan from NGOs \\
\hline BRAC & 130 & 03 & 127 \\
\hline ASA & 065 & 02 & 063 \\
\hline GB $\quad 055$ & 01 & 054 \\
\hline \multicolumn{1}{r|}{ Total= } & $\mathbf{2 5 0}$ & $\mathbf{0 6}$ & $\mathbf{2 4 4}$ \\
\hline
\end{tabular}

The question asked to the respondents was: At what time the respondent gothemselves involved in income generating activities: before or after taking loan from NGOs? From the above table, it can be said that the majority of the respondents (244 out of 250 respondents) expressed a positive attitude towards micro-credit program since they started to involve in income generating activities after taking loan from micro-credit institutions. There is also a reason behind this. In order to repay the loan amount in time, they need to involve in income generating activities and make profit to leave at least with happiness. Their involvement indirectly contributes to GDP, which helps to reduce poverty from Bangladesh[17].

\section{A response about the opinion of respondents about contribution of income generating activities to alleviate poverty:}

The researcher used the frequency tabulation to present the age of the respondents. Table- 7 in the following presented the results:

Table 7: Opinion of respondents about contribution of income generating activities to reduce poverty

\begin{tabular}{|l|c|c|c|}
\hline \multirow{2}{*}{ Name of NGOs } & \multirow{2}{*}{ No. of Respondents } & \multicolumn{2}{|c|}{ Opinion } \\
\cline { 2 - 4 } & & Yes & No \\
\hline BRAC & 130 & 130 & -- \\
\hline ASA & 065 & 065 & --- \\
\hline GB $\quad 055$ & 055 & -- \\
\hline \multicolumn{1}{|c|}{ Total= } & $\mathbf{2 5 0}$ & $\mathbf{2 5 0}$ & -- \\
\hline
\end{tabular}

The question asked to the respondents was: Does the increased income generated from the involvement inincomegenerating activities contribute to alleviate poverty? From the above table, it can be concluded with a guarantee that increased income earned by respondents through involving in income generating activities contributes to poverty alleviation since all of the respondents said yes to this question[18].

Response about opinion of respondents about the relationship between micro-credit and income generating activities:

The researcher used the frequency tabulation to present the age of the respondents. Table- 8 in the following presented the results: 
Table 8: Relationship between micro-credit and income generating activities

\begin{tabular}{|l|c|c|c|}
\hline \multirow{2}{*}{ Name of NGOs } & \multirow{2}{*}{ No. of Respondents } & \multicolumn{2}{|c|}{ Opinion } \\
\cline { 3 - 4 } & & Yes & Yes \\
\hline BRAC & 130 & 126 & 04 \\
\hline ASA & 065 & 062 & 03 \\
\hline GB $\quad 055$ & 052 & 03 \\
\hline \multicolumn{1}{|c|}{ Total= } & $\mathbf{2 5 0}$ & $\mathbf{2 4 0}$ & $\mathbf{1 0}$ \\
\hline
\end{tabular}

The question asked to the respondents was: Is there any relationship between micro-credit and income generating activities? From the above table, it can be summarized that micro-credit program helps to the involvement in income generating activities and finally reduce the poverty since the majority (240 out of 250) respondents said yes[19].

\section{Influence of micro-credit program on poverty alleviation:}

Based on the response on a 5-scale Likert table, the following table presents the percentage of each alternative of each item, its mean, $t$-test value and significance level:

Table 9: Relationship between micro-credit and income generating activities

\begin{tabular}{|c|c|c|c|c|c|c|c|c|}
\hline Question & $\begin{array}{c}\text { Very } \\
\text { Satisf } \\
\text { ied } \\
(\%)\end{array}$ & $\begin{array}{c}\text { Satisf } \\
\text { ied } \\
(\%)\end{array}$ & $\begin{array}{c}\text { Neut } \\
\text { ral } \\
(\%)\end{array}$ & $\begin{array}{c}\text { Dissa } \\
\text { tisfie } \\
\text { d } \\
(\%)\end{array}$ & $\begin{array}{c}\text { Very } \\
\text { Dissa } \\
\text { tisfie } \\
\text { d } \\
(\%)\end{array}$ & $\begin{array}{c}\text { Mean } \\
(5)\end{array}$ & $\begin{array}{l}\text { T-test } \\
\text { value }\end{array}$ & $\begin{array}{c}\text { Sig. } \\
\text { Lev. } \\
(2- \\
\text { tailed) }\end{array}$ \\
\hline $\begin{array}{l}\text { 1. Economic condition of the } \\
\text { family }\end{array}$ & 60.0 & 35.0 & 02.0 & 01.0 & 02.0 & 4.96 & 13.76 & 0.000 \\
\hline $\begin{array}{l}\text { 2. Involvement in income } \\
\text { generating activities }\end{array}$ & 58.0 & 32.0 & 04.0 & 04.0 & 02.0 & 4.90 & 09.35 & 0.000 \\
\hline $\begin{array}{l}\text { 3. Loan amount got from } \\
\text { NGOs }\end{array}$ & 05.0 & 31.0 & 06.0 & 50.0 & 08.0 & 3.76 & 01.58 & 0.072 \\
\hline 4. Contribution to GDP & 52.0 & 28.0 & 15.0 & 03.0 & 02.0 & 4.82 & 07.55 & 0.002 \\
\hline 5. Financial condition change & 64.0 & 32.0 & 01.0 & 02.0 & 01.0 & 4.97 & 14.32 & 0.000 \\
\hline 6. Confidence build-up & 52.0 & 30.0 & 14.0 & 03.0 & 01.0 & 4.86 & 08.12 & 0.003 \\
\hline $\begin{array}{l}\text { 7. Motivation towards small } \\
\text { business }\end{array}$ & 65.0 & 30.0 & 01.0 & 02.0 & 02.0 & 4.96 & 14.22 & 0.000 \\
\hline Total average $=$ & & & & & & 4.75 & 09.84 & 0.011 \\
\hline
\end{tabular}

From the above table, it can be seen that, except the condition of getting a sufficient loan from NGOs in all other cases, respondents thought micro-credit has become able to reduce poverty and initiated financial solvency. Here, t-test expressed significance at 0.05 levels and degrees of freedom at 249 equals 1.98 . The mean value is 4.75 , $\mathrm{t}$-value is (9.84) is higher than the tabulated value of 1.98 and the significance level is 0.011 which is lower than 0.05 . It indicates that poverty alleviation, micro-credit program has positive influence[20].

\section{Relationshipbetween micro-credit program and poverty alleviation:}

Pearson correlation was used to express the relationship between micro-credit program and poverty alleviation.

Table 10: relationship between micro-credit program and poverty alleviation

\begin{tabular}{|l|l|c|}
\hline & & Poverty Alleviation \\
\hline Micro-credit program & $\begin{array}{l}\text { Pearson Correlation Sig. (2-tailed) } \\
\text { [Sig. At 1\% level] }\end{array}$ & $0.582^{* *}$ \\
\cline { 2 - 3 } & & 0.000 \\
\hline
\end{tabular}

The above table states that correlation co-efficient, $r$ is 0.582 and $p$-value is 0.000 , which is significant. It concludes that the more the spread of micro-credit program will be, the more the poverty alleviation will be possible[21]. 


\section{Regression analysis on influence of micro-credit program on poverty alleviation:}

The dependent variable is poverty alleviation and the independent variable is a micro - credit program. Proxies for independent variable are: loan given, involve credit takers in income generating activities, make credit takers, self-dependent, change their financial and economic condition and motivate them to start a small business. Regression resultsare given below:

Table 11: Regression analysis on influence of micro-credit program in poverty alleviation

\begin{tabular}{|c|c|c|}
\hline Variables & Coefficients & P-value $(P>|t|)$ \\
\hline Poverty Alleviation & ------ & \\
\hline Loan given & 42.785 & $0.003 * *$ \\
\hline $\begin{array}{l}\text { Involvement in income generating } \\
\text { activities }\end{array}$ & 73.623 & $0.001 * *$ \\
\hline Self-dependency of women & 46.408 & $0.004 * *$ \\
\hline $\begin{array}{l}\text { Financial and economic condition } \\
\text { development }\end{array}$ & 96.961 & $0.001 * *$ \\
\hline $\begin{array}{l}\text { Motivation toward small business } \\
\text { development }\end{array}$ & 75.635 & $0.001 * *$ \\
\hline \multirow[t]{2}{*}{ Constant } & 754.6834 & $0.031 * *$ \\
\hline & $\begin{array}{l}\text { Number of observations }= \\
250 \\
\mathrm{~F}(5,249)=\mathbf{8 9 . 9 5} \\
\text { Probe }>\mathrm{F}=0.0001 \\
\text { R-squared }=\mathbf{0 . 9 8 7 5} \\
\text { Adj. R-squared }=0.9850 \\
(* * \text { Sig. Level at } 5 \%)\end{array}$ & \\
\hline
\end{tabular}

From the above table, it can be said that independent variables can explain $98.75 \%$ of the dependent variable. Since, Prob $>F$ value is less than 0.05 , the model is significant and $p$-value of less than 0.05 indicates that all the variables are significant.Thus, it can be said that micro-credit program has a positive impact on poverty alleviation[22].

\section{Conclusion}

In Bangladesh more than thousands of NGOs are carrying out micro-credit operations. But, unfortunately the morbid situation of our socioeconomiccondition, especially in the rural settings is evident. What has been explained earlier in this writing is just a model. A model is which tries to attain some sort of success with its perseverance, devotion and commitment. Not only selected three NGOs, but also other NGOs are also playing a significant role in reducing poverty in Bangladesh. To some extent, selected three NGOs have been successful too, as the case of study areas reveals such. In the light of the above discussion, it can be said that as a powerful tool of poverty reduction programs of NGOs, micro-credit helps the creditors to reduce poverty more effectively. On the other hand, creditors have been able to engage with income generating activities after receiving credit for NGOs and income-generating activities positively influences poverty reduction. So it is obvious that NGOs are playing a positive and significant role in reducing poverty in Bangladesh by providing micro-credit to the poor people. The following conclusions and recommendations may be drawnto the source of the findings in this study:

1. Special care should be given to the ultra-hard core poor and destitute group of people.

2. Women should be given special concern in micro credit activities. So that they can be well-off economically.

3. NGO should increase social awareness which influences poverty reduction.

4. Poverty alleviation should be the single aim. 


\section{References}

[1] M. K. Shukran, F. Rahman, A Grameen Bank Concept: Micro-credit and Poverty Alleviation Program in Bangladesh, International Conference on Emerging Trends in Computer and Image Processing, Bangkok, 12 (1), 2011, 47-51.

[2] M. J. A. Chowdhury, D. Ghosh and R. E. Wright, The Impact of Micro-credit on Poverty: Evidence from Bangladesh, Centre for Economic Policy Research (CEPR)90-98 Goswell Road London, England EC1V 7DB, Institute for the Study of Labor (IZA) Schaumburg-Lippe-Strasse D-53113 Bonn Germany May 2002.

[3] A. K. M. M. Rahman, NGO and Development: Myth and Reality, (A. H. Development Publishing House, Dhaka-2010)

[4] M. M. Ahmed, Donors NGOs the State and Their Clients in Bangladesh, (The Arkleton Trust, 2000)

[5] M. M. Khan, From Government to Governance: Expanding the Horizon of Public Administration to Public Management, (The University Press limited-Dhaka, 2013).

[6] M. N. Haq and S. Hussain, Rural Development Programs and the Role of NGOs in Bangladesh, in M. A. Quddus (Ed.), Rural Development in Bangladesh: Strategies and Experiences, (Comilla: Bangladesh Academy of Rural Development, 1996) 443-451.

[7] M. I. Khan and S. R. Howlader, Does Approach Matter in Poverty Reduction: An Empirical Study on Micro-credit Food Assistance and Employment Programs in Rural Bangladesh(Academic Press and Publishers Limited-Dhaka, 2003).

[8] S. Ahmed and M. Rafi, NGOs and Evaluation: the BRAC Experience, World Bank Conference on Evaluation and Poverty Reduction, Washington, D.C., U.S.A.June 14-15, 1999. BRAC Centre, 75 Mohakhali, Dhaka

[9] A. H.M. K. Ahsan, Role of NGO's Micro-credit Program in Poverty Reduction in Bangladesh: A Study on Some Selected NGOs, Pakistan Journal of Social Sciences 3 (8), 2005, 1056-1059.

[10] Latifee, H. I. (2006). The Future of Microfinance: Visioning the Who, What, When, Where, Why, and How of Microfinance Expansion Over the Next 10 Years. Washington: 2006 Global Summit, The Microcredit Summit Campaign, A Project of Results Educational Fund.

[11] Yunus, M. (1985). Grameen Bank: The Main Enemy of Professional Bankers and Moneylenders. The Weekly Bichittra, No.31, January 11, p. 21.

[12] Nahar, N. (2006). Role of Grameen Bank in Poverty Alleviation in Bangladesh: A Study on Selected Area. M. Phil Thesis. Department of Accounting and Information System, Islamic University, Kustia, Bangladesh.

[13] Ahmed and Hossain (1984). Rural Poverty Alleviation in Bangladesh: Experiences and policies, FAO, Rome.

[14] Alamgir, M. (1978). Bangladesh: A Case of Below Poverty Level Equilibrium Trip. Dhaka: The Bangladesh Institute of Development Studies.

[15] National Accounts Statistics, (2005). (Provisional Estimates of GDP, 2004-05 and Final Estimates of GDP, 2003-04), Bangladesh Bureau of Statistics. S. R. Khandker and O. H. Chowdhury (1996), "Targeted Credit Program and Rural Poverty in Bangladesh," World Bank Discussion Papers 336 (Washington, D.C.: World Bank, 1996), p.23, Population and Housing Census (2011). Preliminary Result Dhaka: Bangladesh Bureau of Statistics. Statistics Division, Ministry of Planning, Bangladesh.

[16] Ahmed, S. Address by Governor, Bangladesh Bank, SAARCFINANCE Governors' Symposium on Microcredit, Held in Dhaka, Bangladesh during February 15-16, 2006, SAARCFINANCE Cell, Research Department, Bangladesh Bank, Dhaka, Bangladesh.

[17] D. Patrick. \& A. Huybrechts, "The Impact of Microcredit on the Poor in Bangladesh" Alternatives 30 (2005), 165-189

[18] Akter, S. (1996). Rural Women in Micro Credit Programs for Poverty Alleviation in Bangladesh- Participation and Constraint to their Activities, Bank Parikrama, Vol., xxi-Nos.3 \& 4.

[19] Khan, Z.A., "Ultra Poor Program of PKSF: A milestone in Microcredit Lending", The Financial Express, April 16, 2007, Palli Karma Shahayak Foundation (PKSF), Dhaka, Bangladesh.

[20] Azam, G. (1997). Poverty and old age problem of rural Families living in subsistence level, Dhaka: Bangladesh, Program for research on poverty alleviation, Grameen Trust, Grameen Bank Bhaban.

[21] Asaduzzaman \& Akter (1990). Evaluation of Poverty Alleviation Program. The Bangladesh Institute of Development Studies, Vol. II, 1990.

[22] Rahman, M. (1999). Grameen bank Finance and Entrepreneurship Development in Bangladesh: A Case Study of Some Selected Areas, Unpublished Doctoral Dissertation, Islamic University, Kustia University, Bangladesh. 